\title{
Mean Circulation and Variability of the Tropical Atlantic during 1952-2001 in the GECCO Assimilation Fields
}

\author{
Benjamin Rabe and Friedrich A. Schott \\ IFM-GEOMAR, Leibniz-Institut für Meereswissenschaften an der Universität Kiel, Kiel, Germany \\ ARMIN KÖHL \\ Institut für Meereskunde, Zentrum für Meeres und Klimaforschung, Universität Hamburg, Hamburg, Germany
}

(Manuscript received 23 January 2006, in final form 23 April 2007)

\begin{abstract}
The shallow subtropical-tropical cells (STC) of the Atlantic Ocean have been studied from the output fields of a 50-yr run of the German partner of the Estimating the Circulation and Climate of the Ocean (GECCO) consortium assimilation model. Comparison of GECCO with time-mean observational estimates of density and meridional currents at $10^{\circ} \mathrm{S}$ and $10^{\circ} \mathrm{N}$, which represent the boundaries between the tropics and subtropics in GECCO, shows good agreement in transports of major currents. The variability of the GECCO wind stress in the interior at $10^{\circ} \mathrm{S}$ and $10^{\circ} \mathrm{N}$ remains consistent with the NCEP forcing, although temporary changes can be large. On pentadal and longer time scales, an STC loop response is found between the poleward Ekman divergence and STC-layer convergence at $10^{\circ} \mathrm{S}$ and $10^{\circ} \mathrm{N}$ via the Equatorial Undercurrent (EUC) at $23^{\circ} \mathrm{W}$, where the divergence leads the EUC and the convergence, suggesting a "pulling" mechanism via equatorial upwelling. The divergence is also associated with changes in the eastern equatorial upper-ocean heat content. Within the STC layer, partial compensation of the western boundary current (WBC) and the interior occurs at $10^{\circ} \mathrm{S}$ and $10^{\circ} \mathrm{N}$. For the meridional overturning circulation (MOC) at $10^{\circ} \mathrm{S}$ it is found that more than one-half of the variability in the upper limb can be explained by the WBC. The explained MOC variance can be increased to $85 \%$ by including the geostrophic (Sverdrup) part of the wind-driven transports.
\end{abstract}

\section{Introduction}

The subtropical-tropical cells (STC) transport subducted waters from the subtropics toward the equatorial zonal currents and upwelling regions, where the water returns poleward within the surface mixed layer (ML; see Liu et al. 1994; McCreary and Lu 1994; Snowden and Molinari 2003; Schott et al. 2004). For the Pacific, decadal changes of the STCs have been derived from observations (McPhaden and Zhang 2002, 2004) and have been linked to changes in equatorial sea surface temperature (SST). For the Atlantic Ocean, a coupled ocean-atmosphere model study by Kröger et al. (2005) has shown connections between the variability of subtropical wind stress and temperature to equa-

\footnotetext{
Corresponding author address: Benjamin Rabe, Climate Sciences, Alfred-Wegener-Institute for Polar and Marine Research, Bussestr. 24, Postfach 120161, 27515 Bremerhaven, Germany. E-mail: benjamin.rabe@awi.de
}

torial SST. Other Atlantic model studies have shown a strong influence on the STC strength and pathways by the meridional overturning circulation (MOC; see Fratantoni et al. 2000; Malanotte-Rizzoli et al. 2000; Jochum and Malanotte-Rizzoli 2001; Hazeleger and Drijfhout 2006) and the type of wind forcing used (Lazar et al. 2002; Inui et al. 2002). High-resolution model experiments by Hüttl and Böning (2006) have further shown a remote influence by changes in the North Atlantic MOC.

Different from the case for the Pacific Ocean, no observational time series exist that cover the Atlantic STC pathways for a long enough time period to study interannual to decadal STC variability. Therefore, we study STC-related processes using output from the German partner of the Estimating the Circulation and Climate of the Ocean (GECCO) consortium assimilation model (Köhl et al. 2006). This assimilation, in our view, has the advantage of not distorting the temperature and salinity conservation equations through the

DOI: $10.1175 / 2007 J P O 3541.1$ 
use of artificial source and sink terms. Instead, it adjusts the initial conditions and surface fluxes to obtain a best fit to the available observations, including satellite-derived sea surface height, temperature and wind stress, and profiles of salinity and temperature from XBT, $\mathrm{CTD}$, and autonomous drifters. One of the disadvantages of the available GECCO version is its coarse horizontal resolution $\left(1^{\circ} \times 1^{\circ}\right)$. At this resolution many processes are not sufficiently resolved, and the results are limited to the physics represented by the model. Therefore, the first focus of our study is a comparison of the simulated mean circulation in the tropical Atlantic with existing observations in order to exemplify the realism of the STC circulation in the model. We concentrate on the warm-water circulation in the upper 500 $\mathrm{m}$ of the water column (Stramma and England 1999; Stramma and Schott 1999) for which a number of recent observational studies have provided mean transport estimates of various circulation branches for comparison. Furthermore, we quantify the adjustments that GECCO applies to the wind stresses, and resulting Ekman and Sverdrup transport differences to the input forcing fields. An important cross-equatorial section from the central tropical Atlantic, for which comparison transports have recently become available, is located around $23^{\circ} \mathrm{W}$ (termed $26^{\circ} \mathrm{W}$ in Brandt et al. 2006). New estimates of the northward transports off Brazil in the $5^{\circ}-11^{\circ} \mathrm{S}$ latitude range by the North Brazil Undercurrent (NBUC) have recently become available from Schott et al. (2005). With regard to the interior STC transports in isopycnal ranges, the thorough analysis of the historical hydrographic database for the mean Atlantic STC transports by Zhang et al. (2003) is an important comparison base for our study.

The second focus of our study is the interannual to decadal variability of the boundary and equatorial circulation of the STCs. The observational comparison base for the variability is even sparser than for the means. At the equator, altimetry (Schouten et al. 2005) and drifters (Lumpkin and Garzoli 2005) recently allowed estimates of the seasonal surface currents; and Giarolla et al. (2005) and Brandt et al. (2006) presented time series and seasonal cycle analysis obtained from moored ADCPs at $23^{\circ} \mathrm{W}$ as part of the Pilot Research Moored Array in the Tropical Atlantic (PIRATA) array. However, time series of transport estimates have not been derived yet from any of these datasets. In any event, altimetry-derived currents cannot serve as independent comparisons, with altimetry being assimilated by GECCO. From a moored array near $10^{\circ} \mathrm{S}$, deployed during 2000-04, Schott et al. (2005) determined transport time series for the NBUC, but large intraseasonal variability caused uncertainties of the amplitude and phase of the annual cycle.

The third part of our study will search for evidence of causes of variability in the STCs, the Equatorial Undercurrent (EUC) transport at $23^{\circ} \mathrm{W}$ and equatorial upwelling and heat content. We will focus on the sections at $10^{\circ} \mathrm{S}$ and $10^{\circ} \mathrm{N}$, as these give an indication of poleward divergence near the surface as well as the pycnocline convergence and transport by the western boundary currents (WBCs); furthermore, they are far enough away from the equatorial regime to avoid the tropical cells (TCs; see Molinari et al. 2003; Zhang et al. 2003). The main question asked in this context is the following: Can we determine the cause of STC anomalies, in particular, are they are "pulled" by anomalous Ekman divergence? Selected anomalies will be discussed regarding the associated thermocline flows that relate the near- and off-equatorial latitudes with the EUC and eastern equatorial upwelling, heat content as well as the local wind forcing. Finally we will investigate the anomalies of the MOC in the region, focusing on the $10^{\circ} \mathrm{S}$ section; in particular, how it might be related to quantities that can be estimated, such as Ekman and Sverdrup transports, or are measurable, like the NBUC.

\section{Model, data, and methods}

The output fields analyzed here are from a recent 50-yr run (1952-2001) of the GECCO model (Köhl et al. 2006). Throughout this paper, the term "ECCO" will be used when referring to previous studies involving the 11-yr realization of this model (see also Köhl et al. 2007). GECCO is a global configuration based on the Massachusetts Institute of Technology general circulation model (MITgcm; Marshall et al. 1997), with $1^{\circ}$ horizontal resolution and 23 depth levels. The GECCO framework uses the adjoint method to bring the model into consistency with available hydrographic and satellite data as well as prior estimates of surface fluxes, such as those of momentum, heat, and freshwater. The prior forcing fields consists in twice-daily wind stress and daily heat and freshwater flux fields from the National Centers for Environmental Prediction (NCEP). These forcing fields are adjusted every 10 days by the method to yield a model state that is dynamically consistent with the model physics and the assimilated data within given error limits. We refer to Stammer et al. (2004) for further details and Wunsch (1996) for a general introduction. Additional prior information for the wind stress is provided on a monthly basis during the last $10 \mathrm{yr}$ by a merged product from National Aeronautics and Space Admininstration (NASA) Scatterometer 
a)

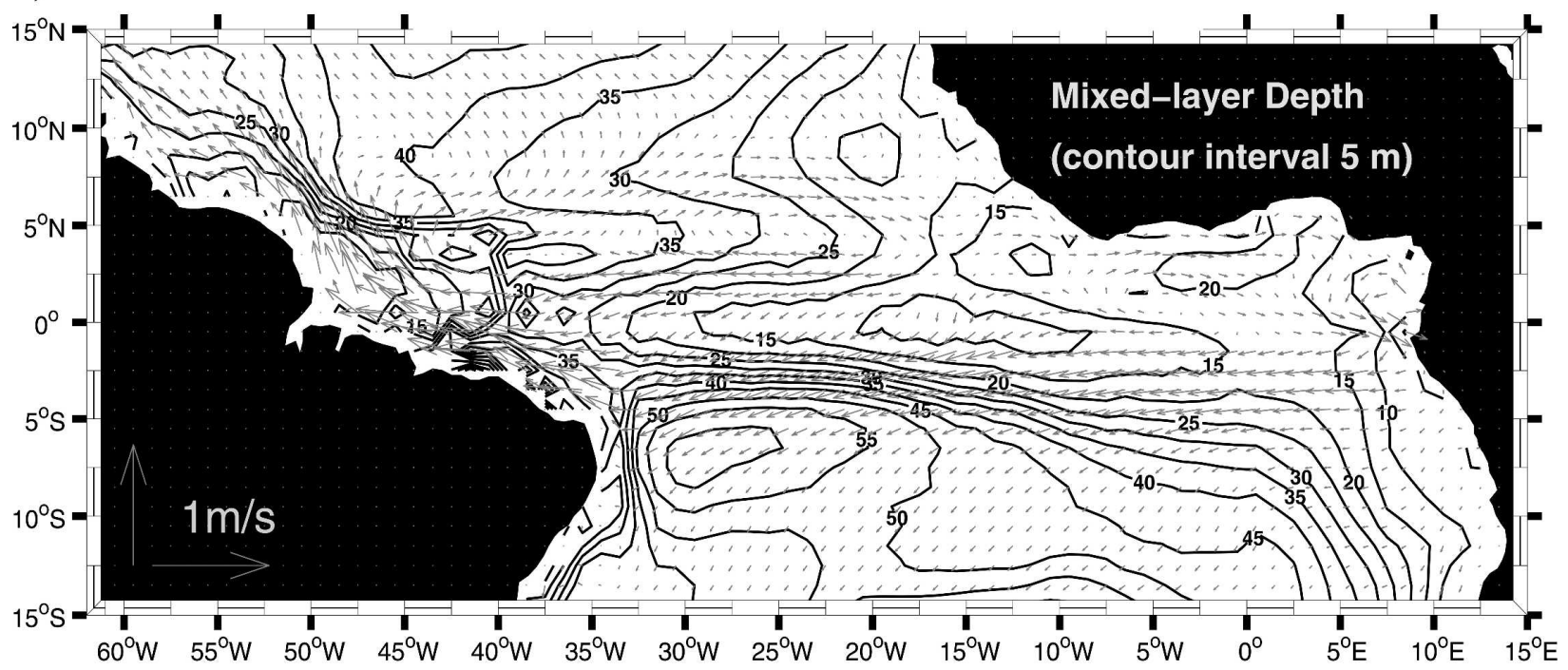

b)

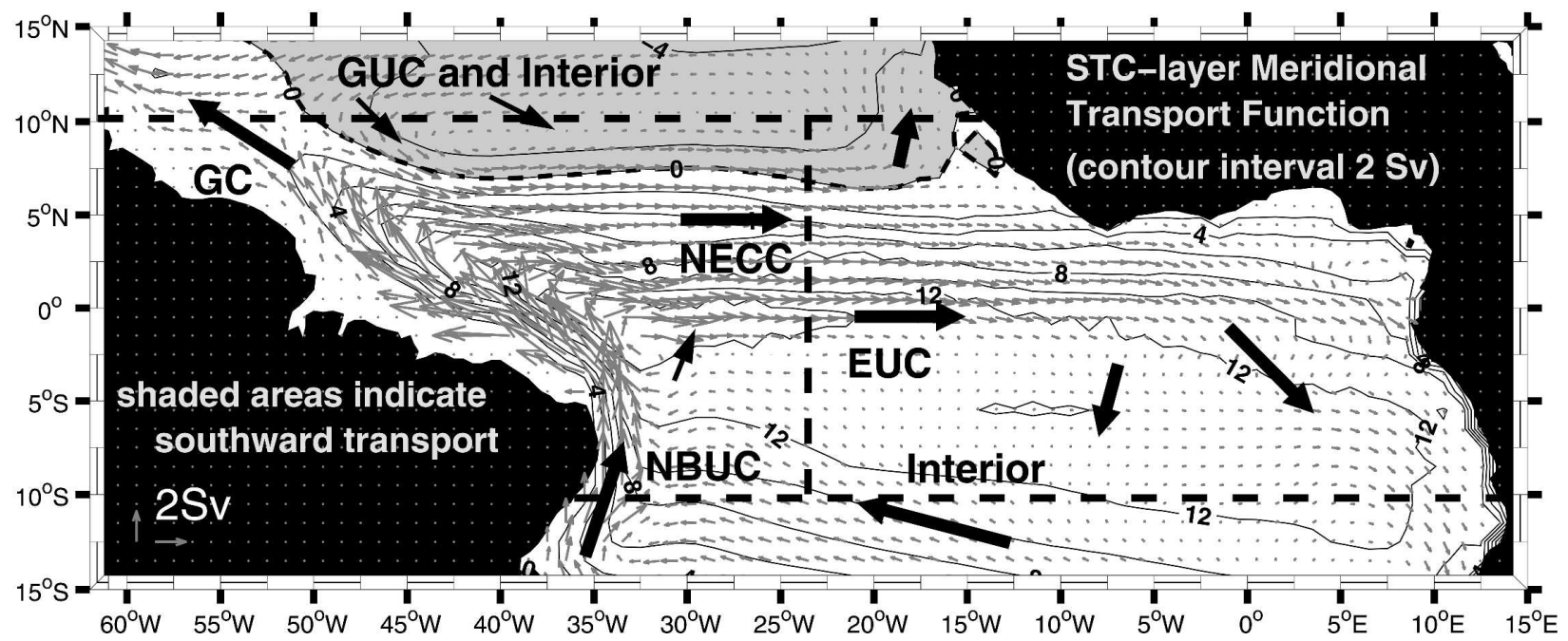

FIG. 1. (a) The $15-\mathrm{m}$ level velocities ( $\mathrm{m} \mathrm{s}^{-1}$; scale at lower left) with mixed layer depth (contours), defined as the depth where $\sigma_{\theta}$ is $0.125 \mathrm{~kg} \mathrm{~m}^{-3}$ higher than the corresponding surface value. (b) The STC layer transports (Sv; scale at lower left), defined for the layer above the isopycnal surface $\sigma_{\theta}=26.7 \mathrm{~kg} \mathrm{~m}^{-3}$ and below the mixed layer, and the pseudostreamfunction, $\psi_{v}$ (contours). The schematic current branches and sections analyzed are also shown (see text for details).

(NSCAT), the European Remote Sensing Satellite (ERS-1/2), and the Quick Scatterometer (QuikSCAT). However, given the availability in time and the small weight applied to the data, this additional information has only a minor impact on the solution.

Our region of interest is the tropical Atlantic between $15^{\circ} \mathrm{S}$ and $15^{\circ} \mathrm{N}$ (Fig. 1), and only GECCO output from this region is used in the analysis. From the available monthly data we use temperature, salinity, zonal, meridional, and vertical velocity. The adjusted surface momentum fluxes were averaged to monthly values. For the purpose of calculating horizontal transports in density layers, the vertical profiles at each individual horizontal grid point are linearly interpolated with either depth or density as the vertical coordinate. For direct comparison to the model output we choose previously published observational data that is not assimilated in GECCO. We are evaluating the extent of covariability between different time series of transports and heat content in the model. Throughout this work, unless stated otherwise, all presented correlation values are above the $95 \%$ significance level (see also Bretherton et al. 1999). Wherever explained variance is shown, significant correlation was found between the corre- 
sponding time series. The data filtering referred to in our analysis uses a fifth-order Butterworth Filter as a high- or low-pass filter with a specified cutoff period.

\section{Mean circulation in the STC layer}

\section{a. Large-scale circulation}

In the following we define the STC layer to be between the bottom of the ML and $\sigma_{\theta}=26.7 \mathrm{~kg} \mathrm{~m}^{-3}$. We found this to be the appropriate boundary when looking at the vertical extent of the EUC at $23^{\circ} \mathrm{W}$ (Figs. $2 \mathrm{a}, \mathrm{b})$ and also at the depth of the equatorward flow through the $10^{\circ} \mathrm{S}$ and $10^{\circ} \mathrm{N}$ sections (Figs. 2a,b). The ML (Fig. 1a) is defined to reach to a density that is $0.125 \mathrm{~kg} \mathrm{~m}^{-3}$ higher than the corresponding surface value of $\sigma_{\theta}$, in accordance with previous work (Zhang et al. 2003).

The near-surface flow in GECCO is mostly from east to west and poleward from the equator (Fig. 1a), in agreement with observations from surface drifters (Lumpkin and Garzoli 2005; Grodsky and Carton 2002). To describe the circulation within the STC layer, according to our definition, we vertically integrate the horizontal transport at each grid point within this layer. A good indication of the horizontal STC layer circulation, although not free of divergence, is derived from the cumulative sum of the meridional component, integrated eastward from the western boundary (Fig. 1b). This is similar to the "pseudo streamfunction" definition of Lee and Fukumori (2003) in their model study of the Pacific. Horizontal transport vectors at the center of each grid box are also shown (Fig. 1b). It is evident that most of the equatorward flow from the Southern Hemisphere is via the NBUC along the western boundary, as also obvious from the velocity and $\sigma_{\theta}$ cross section at $10^{\circ} \mathrm{S}$ (Fig. 2a).

\section{b. Subtropical meridional circulation in the STC layer}

\section{1) $10^{\circ} \mathrm{S}$}

The mean northward STC layer transport at $10^{\circ} \mathrm{S}$ between the coast and $29^{\circ} \mathrm{W}$ (box A, Fig. 2a) is $12.2 \mathrm{~Sv}$ $\left(1 \mathrm{~Sv} \equiv 10^{6} \mathrm{~m}^{3} \mathrm{~s}^{-1}\right)$, in agreement with the transport of $12.9 \pm 3.5 \mathrm{~Sv}$ in the density range of $\sigma_{\theta}=24.5-26.8 \mathrm{~kg}$ $\mathrm{m}^{-3}$ that Schott et al. (2005) derived for a mean of five shipboard ADCP sections along approximately $10^{\circ} \mathrm{S}$. Note that we define the boundary current to reach to $29^{\circ}$ and not $32^{\circ} \mathrm{W}$, as there is a recirculating component between these two longitudes (Figs. 2a and 1), as also noted by Schott et al. (2005) in the $5^{\circ}$ and $11^{\circ} \mathrm{S}$ ship sections (see also Fig. 2b). Some equatorward STC layer flow occurs in the interior (Fig. 2a) and noticeable southward flow occurs east of approximately $5^{\circ} \mathrm{E}$. Therefore, we define the interior equatorward STC at $10^{\circ} \mathrm{S}$ to take place between $29^{\circ} \mathrm{W}$ and $5^{\circ} \mathrm{E}$, but it occurs mostly west of $10^{\circ} \mathrm{W}$ (Fig. 2c). The corresponding timemean total interior STC transport, taking both northand southward components into account, is $4.3 \mathrm{~Sv}$, and it is $5.2 \mathrm{~Sv}$ when only the equatorward flow is considered. The geostrophic interior STC transport from GECCO, when referenced to $1200 \mathrm{~m}$, turns out to have a total flow of $4.8 \mathrm{~Sv}$ and an equatorward component of 5.4 Sv. This confirms that the no-motion assumption at $1200 \mathrm{~m}$ of Zhang et al. (2003) is a reasonable choice.

\section{2) $10^{\circ} \mathrm{N}$}

At $10^{\circ} \mathrm{N}$ the boundary versus interior distribution of equatorward STC flow differs between GECCO and the observations: the analysis of the hydrographic climatology showed that a fraction of $3 \mathrm{~Sv}$ is concentrated near the boundary [the Guyana Undercurrent (GUC); Wilson et al. 1994], versus $2 \pm 0.7 \mathrm{~Sv}$ for the interior (Zhang et al. 2003). In GECCO, the boundary current region at $10^{\circ} \mathrm{N}$ is wider. Within the STC layer, $2.5 \mathrm{~Sv}$ flow northward as a result of the presence of a mean Guyana Coastal Current in GECCO and only a weak equatorward flow occurs below, which is around $1.1 \mathrm{~Sv}$, giving 1.4 Sv of absolute transport near the western boundary away from the equator. The equivalent of the GUC is found farther east in GECCO and is therefore part of the interior STC layer flow, which occurs in a broad longitude band east of $53^{\circ} \mathrm{W}$, amounting to $2.7 \mathrm{~Sv}$ toward the equator in the STC layer. Together with the equatorward flow near the boundary this amounts to 3.8 Sv, slightly lower than the Wilson et al. (1994) and Zhang et al. (2003) estimates but, considering the error, close to the total of $5 \pm 0.7 \mathrm{~Sv}$.

\section{c. Equatorial circulation at $23^{\circ} \mathrm{W}$}

To study the whole of the STC, we have not only to quantify the subtropical meridional circulation but also its relationship to the zonal currents at the equator. Similar to the previous section, we first compare the zonal current and density structure in GECCO to available subsurface measurements. We concentrate on the covariability of the subtropics and the central and eastern equatorial Atlantic, because this region is important for the regional climate there (Foltz et al. 2003). In GECCO, no North and South Equatorial Undercurrents (NEUC and SEUC) can be seen. Instead, the EUC is wider and has a more deep reaching core, as is obvious when comparing the GECCO EUC $23^{\circ} \mathrm{W}$ (Fig. 2c) with observations averaged between $23^{\circ}$ and $29^{\circ} \mathrm{W}$ (section in Fig. 2d) by Brandt et al. 2006). The EUC also reaches down to below $300 \mathrm{~m}$ south of the equator, 

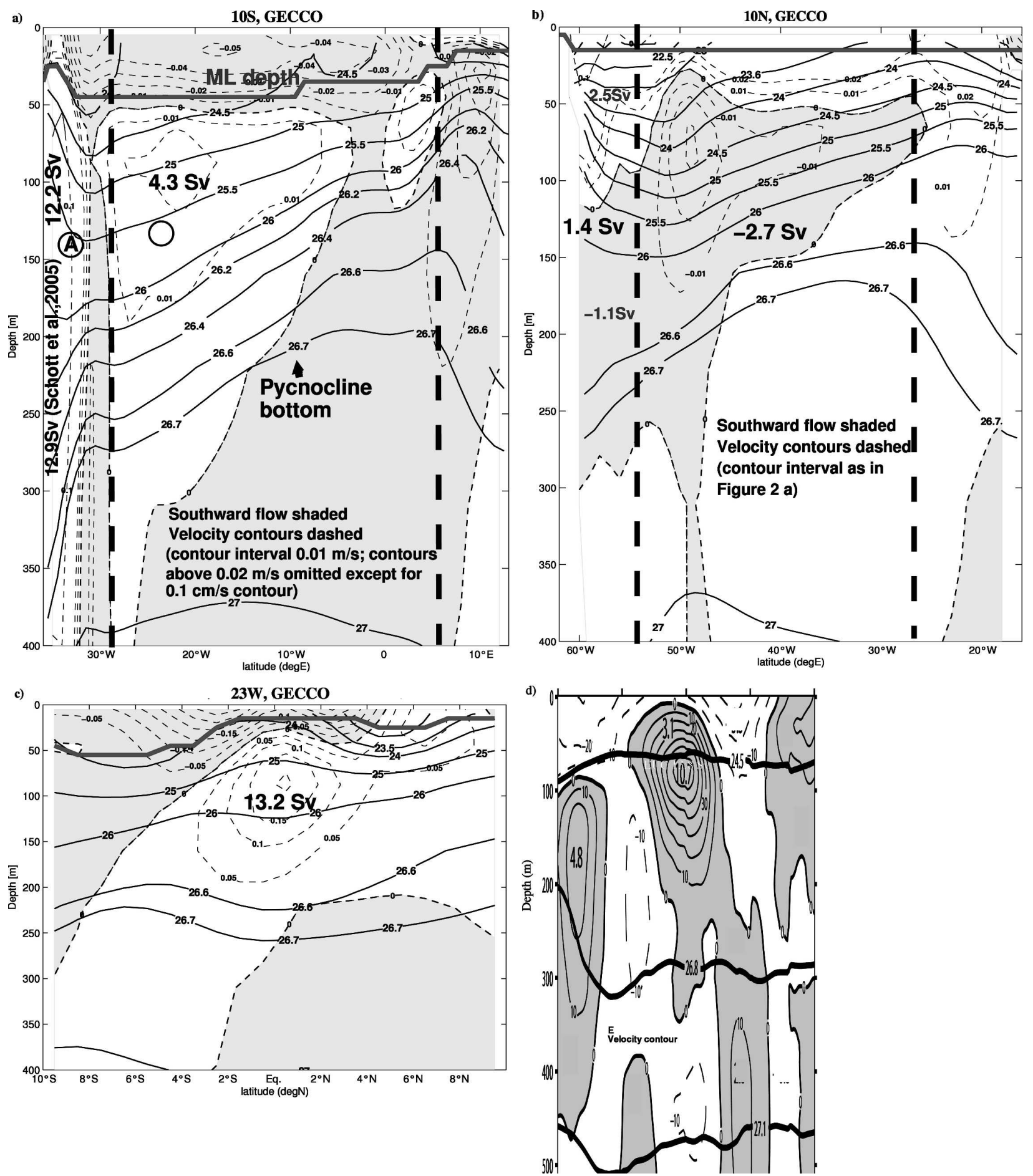

FIG. 2. Time-mean cross-sectional velocity and $\sigma_{\theta}$ for the (a) GECCO zonal section along $10^{\circ} \mathrm{S}$ and (b) along $10^{\circ} \mathrm{N}$. The meridional section along $23^{\circ} \mathrm{W}$ (c) in GECCO and (d) from ADCP observations between $23^{\circ}$ and $29^{\circ} \mathrm{W}$ (after Brandt et al. 2006). Box boundaries (dashed white lines) and corresponding mean transport estimates are also shown, where appropriate. All transports are within the STC layer, between the bottom of the mixed layer, here marked as a thick white line, and the $\sigma_{\theta}=26.7 \mathrm{~kg} \mathrm{~m}^{-3}$ isopycnal (see also Fig. 1). In (a)-(c) the labels of velocity contours are in meters per second and gray shading denotes southward or westward flow. In (d) the labels of velocity contours are in centimeters per second and gray shading denotes eastward flow. 
where the SEUC normally has its maximum strength at $23^{\circ} \mathrm{W}$. Observations also show a deeper penetration of the southern SEC (sSEC), which may also inhibit equatorward STC layer flow in reality. Furthermore, the distinction between the NECC and EUC is not always clear in GECCO, as the northern SEC does not penetrate deep enough to separate the NECC and EUC. Possible reasons for the differences in observed and GECCO current structure are the coarse horizontal resolution or the choice of mixing scheme. The total EUC transport in GECCO at $23^{\circ} \mathrm{W}$ is $13.2 \mathrm{~Sv}$, similar to a recent estimate of $13.8 \mathrm{~Sv}$ from the mean of 11 ship sections between $23^{\circ}$ and $29^{\circ} \mathrm{W}$ (Brandt et al. 2006). However, this apparent agreement between the GECCO EUC and observed EUC transports has to be seen in comparison to the lack of off-equatorial undercurrents (NEUC and SEUC) in GECCO, such that the total combined eastward undercurrent transport in GECCO is substantially less than observed.

\section{d. STC paths between the subtropics and the equator}

One of the important processes within the STC is the subduction of equatorward STC layer flow. This can be seen in the poleward shoaling of the isopycnals within the upper part of the STC layer toward the subtropical subduction zones (Fig. 2c). Most of the subducted flow in the Southern Hemisphere west of $30^{\circ} \mathrm{W}$ appears to merge into the NBUC instead of directly into the EUC and the equatorial STC layer through the interior window (Fig. 1b). However, because the EUC is wider and deeper than in observations, it transports a small portion, $\sim 1 \mathrm{~Sv}$, of the interior flow from $10^{\circ} \mathrm{S}$ directly eastward without entering the NBUC. This circulation pattern was also found in Lagrangian particle tracking applied to the GECCO fields (not shown). In other model studies the role of the southern interior window has been found to be strongly dependent on the strength and pattern of the wind forcing in the climatology used (Lazar et al. 2002; Inui et al. 2002). Different wind stress patterns will cause bands of Ekman upwelling that extend westward to different longitudes from the eastern upwelling domes (Schott et al. 2004), bringing up stratified thermocline waters into the paths of the more homogeneous subduction waters. They are thus forming a potential vorticity barrier (see also Gill 1982, p. 482), forcing westward detours of the STC flows.

North of the equator, previous model studies suggest that southward STC layer transport generally does not reach the equator via the mean flow, because of the westward extension of the northern potential vorticity barrier associated with the intertropical convergence zone. However, variability in the northern STC has been linked to changes at the equator (e.g., Kröger et al. 2005). In GECCO, most of the transport from the Northern Hemisphere is through the equivalent of the GUC [see section $3 b(2)$ ] and subsequently turns eastward within the NECC before eventually splitting close to the African coast: one portion flowing northward, in agreement with the surface drifter analysis by Lumpkin and Garzoli (2005), and the remainder continuing eastward into the Gulf of Guinea.

\section{Forcing adjustment at $10^{\circ} \mathrm{S}-\mathrm{N}$}

\section{a. Mean wind stress}

GECCO wind stress forcing starts out with NCEP, then the model adjusts the forcing fields during the assimilation process. To see the extent of this adjustment, we compare the wind stresses of GECCO with NCEP, the initially applied forcing of the model, and with the 40-yr European Centre for Medium-Range Weather Forecasts (ECMWF) Reanalysis (ERA-40) wind stresses, which are not assimilated but also cover most of the GECCO time series under study. We are comparing Ekman and Sverdrup transports across the zonal sections at $10^{\circ} \mathrm{S}$ and $10^{\circ} \mathrm{N}$, because these give a measure of the poleward divergence near the surface and will be used in the remainder of this paper to study STC-related convergence and transports by the WBC. Note that for NCEP and GECCO we average over the whole $50 \mathrm{yr}$, although using only the $44 \mathrm{yr}$ covered by ERA-40 gives a similar result.

In both zonal sections, the time-mean Ekman transports, integrated zonally from the edge of the WBC (Fig. 3a), show the highest poleward transport near the western boundary and a fairly smooth leveling toward the east. At $10^{\circ} \mathrm{S}\left(10^{\circ} \mathrm{N}\right)$ outside the WBC, GECCO has zonal mean Ekman transports similar to those derived from monthly mean NCEP winds, but the net is about 2 Sv lower (higher) than the Ekman transport derived from $44 \mathrm{yr}$ of ERA-40 (Fig. 3). This means that, at least in the time mean and over the whole basin away from the equator, the zonal wind stress component in GECCO is almost not modified against NCEP and lightly shifted in the direction opposite to ERA-40 in relation to NCEP. The GECCO Sverdrup transport at $10^{\circ} \mathrm{S}$ shows an $\sim 1$-Sv difference to NCEP and ERA-40 (Fig. 3b), with GECCO falling in between the two. At $10^{\circ} \mathrm{N}$ the GECCO Sverdrup transport differs from all other wind products.

Like the Ekman transport, the integrated southward Sverdrup transport increases from west to east, but shows local signals in the eastern part of the basin, in particular at $10^{\circ} \mathrm{S}$. There, the differences between the wind products are locally much larger than elsewhere. 

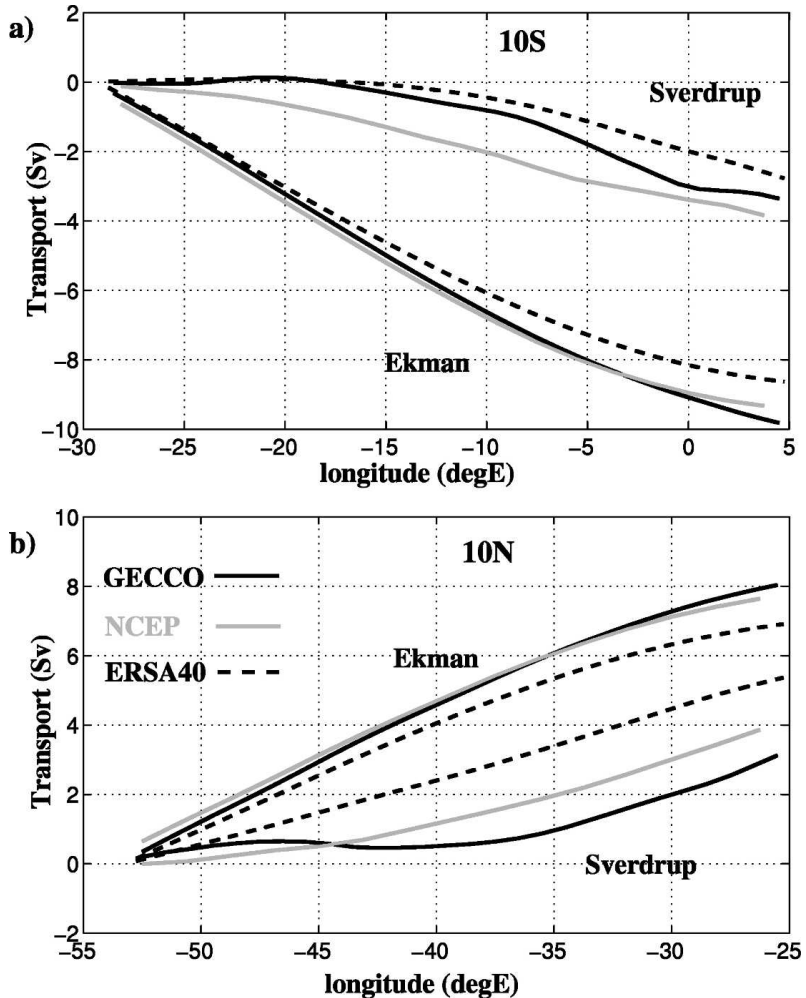

FIG. 3. Comparison of mean transports from different wind stress products: NCEP (gray), ERA-40 (dashed gray) and GECCO (solid) for (a) $10^{\circ} \mathrm{S}$ and (b) $10^{\circ} \mathrm{N}$. The meridional Ekman and Sverdrup transports are shown against longitude, cumulative from the western boundary.

However, there are less constraining ocean data in this region than in other parts of the tropical Atlantic. The comparison shows that there are noticeable differences between all three wind products and no obvious reason to give preference to any of the three. However, the most suitable for our analysis of STC-related processes are the GECCO fields, because they are consistent with the ocean circulation in the model.

\section{b. Shipboard observational data}

Few published observational analyses are available north and south of the equator for comparison with the GECCO fields, apart from the ones mentioned in section 3. Of particular relevance to the role of wind forcing and estimates of Ekman and ageostrophic ML transports at the latitudes under study are data published by Chereskin and Roemmich (1991). They give an estimate of ML transport from vessel-mounted ADCP velocity measurements and Ekman transport from ship wind stress. At approximately $11^{\circ} \mathrm{N}$ in March 1989, Chereskin and Roemmich (1991) find $9.3 \mathrm{~Sv}$ of ageostrophic transport from the surface to the ML depth and an Ekman transport of $8.8 \pm 1.9$ Sv. Consid-

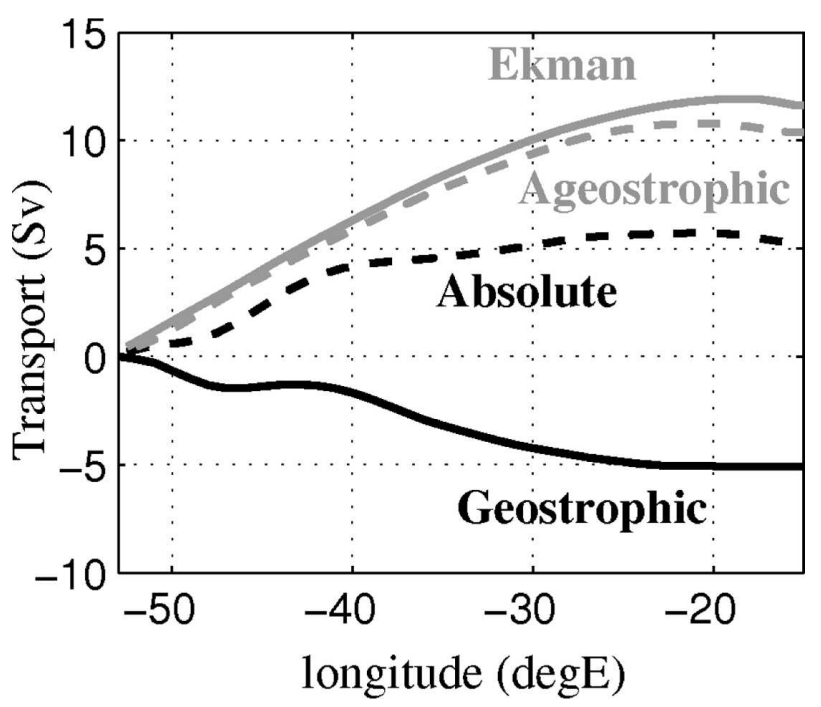

FIG. 4. GECCO cumulative mixed layer transports along $10^{\circ} \mathrm{N}$ during March 1989. The absolute (dashed black), ageostrophic (dashed gray), geostrophic (solid black), and Ekman (solid gray) transports are shown.

ering the error due to synopticity and the southward bend in the ship-survey track in the west, this is in reasonable agreement with the GECCO ML ageostrophic transport of around $10 \mathrm{~Sv}$ and an Ekman transport from GECCO winds of $12 \mathrm{~Sv}$ at $10^{\circ} \mathrm{N}$ during the same month (Fig. 4).

\section{c. Variability}

As in the mean circulation, the GECCO adjustment of the wind stresses is evident in the anomalies of the Sverdrup and Ekman transports at $10^{\circ} \mathrm{S}$ and $10^{\circ} \mathrm{N}$ from their respective mean seasonal cycles (Fig. 5). At $10^{\circ} \mathrm{S}$ the range of Ekman transport variability is similar for all wind products, as denoted by the respective standard deviations for NCEP (1.4 Sv), GECCO (1.4 Sv), and ERA-40 (1.2 Sv). The corresponding values for the Sverdrup transport anomalies are all similar at 2.7, 2.7, and $2.0 \mathrm{~Sv}$, respectively. At $10^{\circ} \mathrm{N}$, standard deviations in Ekman and Sverdrup transports are of similar magnitude as at $10^{\circ} \mathrm{S}$. Although the standard deviations are largely similar in all wind products, the Sverdrup transports can differ considerably at times.

\section{Mixed layer and STC layer transport variability at $10^{\circ} \mathrm{S}-\mathbf{N}$}

\section{a. Local wind driving and STC layer components}

In the interior basin, the meridional ML transport variability for the $10^{\circ} \mathrm{S}$ and $10^{\circ} \mathrm{N}$ sections (Figs. 6a,b, top) corresponds very closely to the Ekman transports at zero lag. The latter explain around $75 \%$ of the ML transport variance at both $10^{\circ} \mathrm{S}$ and $10^{\circ} \mathrm{N}$, where the 
a)

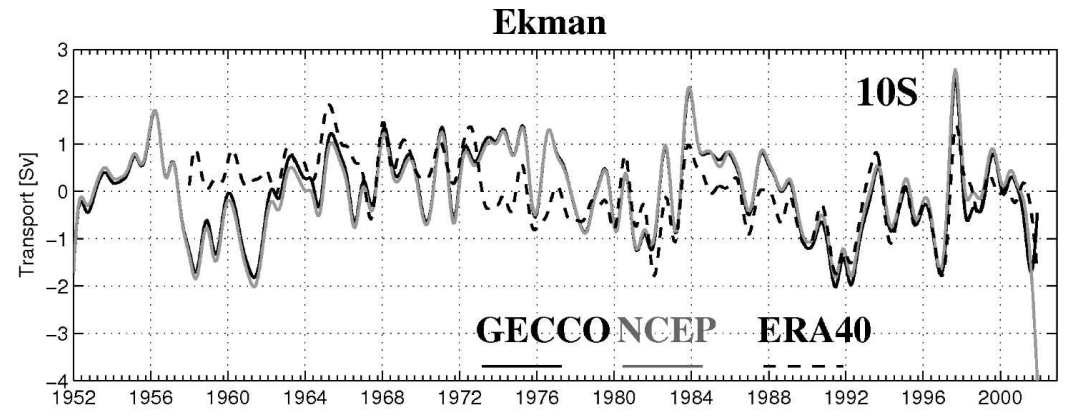

b)

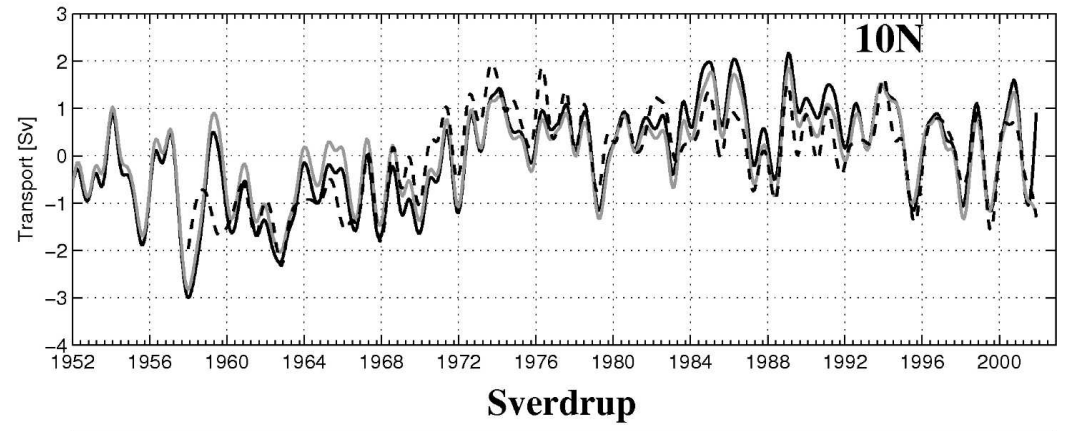

c)

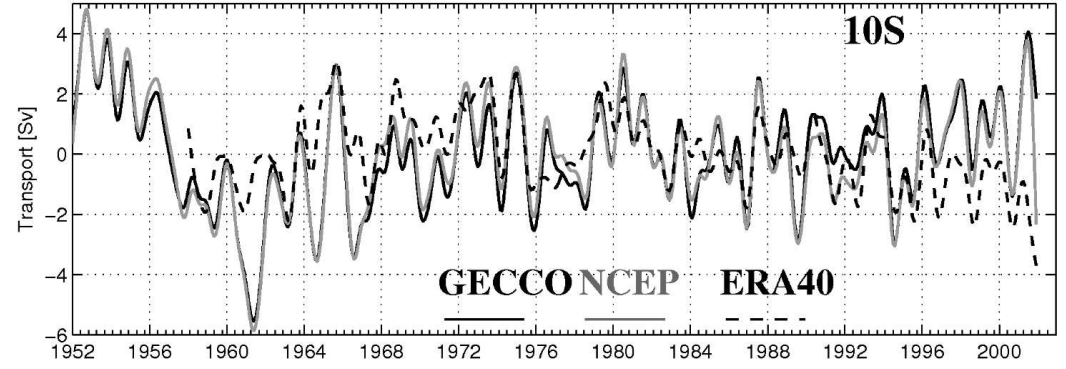

d)

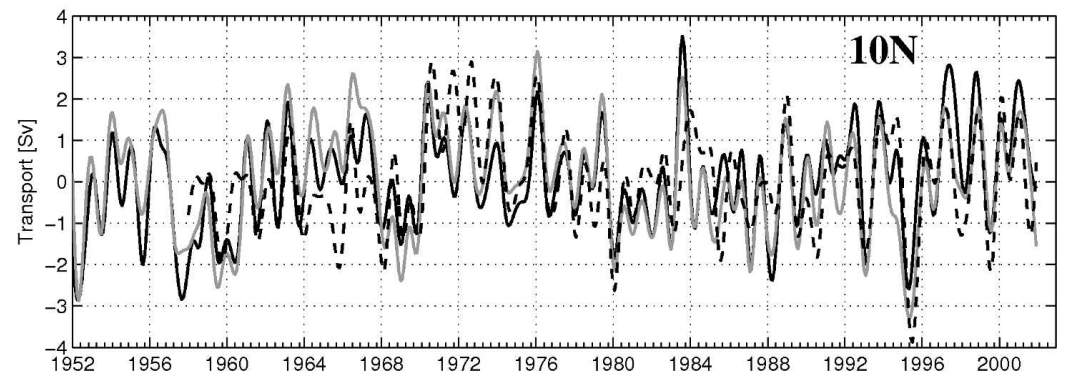

FIG. 5. The 12-month low-pass-filtered anomalies (Sv) from the mean annual cycle of Ekman transports at (a) $10^{\circ} \mathrm{S}$ and (b) $10^{\circ} \mathrm{N}$, from GECCO wind stress (solid) and from NCEP (gray) wind products. (c), (d) As in (a), (b), but for Sverdrup transports.

explained variance reduces by about $10 \%$ for fluctuations of $5 \mathrm{yr}$ and longer. The remainder of the ML transport variance is due to the geostrophic flow.

Interannual variations of the WBC parts of the STC transports are larger than for the interior (Figs. 6a,b, bottom) and are related to the MOC, as will be shown in section 7. On the other hand, the STC layer variability in the WBC is also larger than for the whole meridional STC layer transport at both $10^{\circ} \mathrm{S}$ and $10^{\circ} \mathrm{N}$, which is due to a partial compensation between WBC and interior STC layer transports (Figs. 6a,b, bottom). On time scales below $4 \mathrm{yr}$, this is confirmed by significant anticorrelation between these two parts of the STC-layer transports at both $10^{\circ} \mathrm{S}$ and $10^{\circ} \mathrm{N},-0.5$ and -0.3 , respectively, with around a 1-month lead by the WBC.

Previous work shows an out-of-phase relation between the interior meridional flow and the boundary, suggesting a quasi-stationary Sverdrup response. This was established on seasonal to interannual time scales 

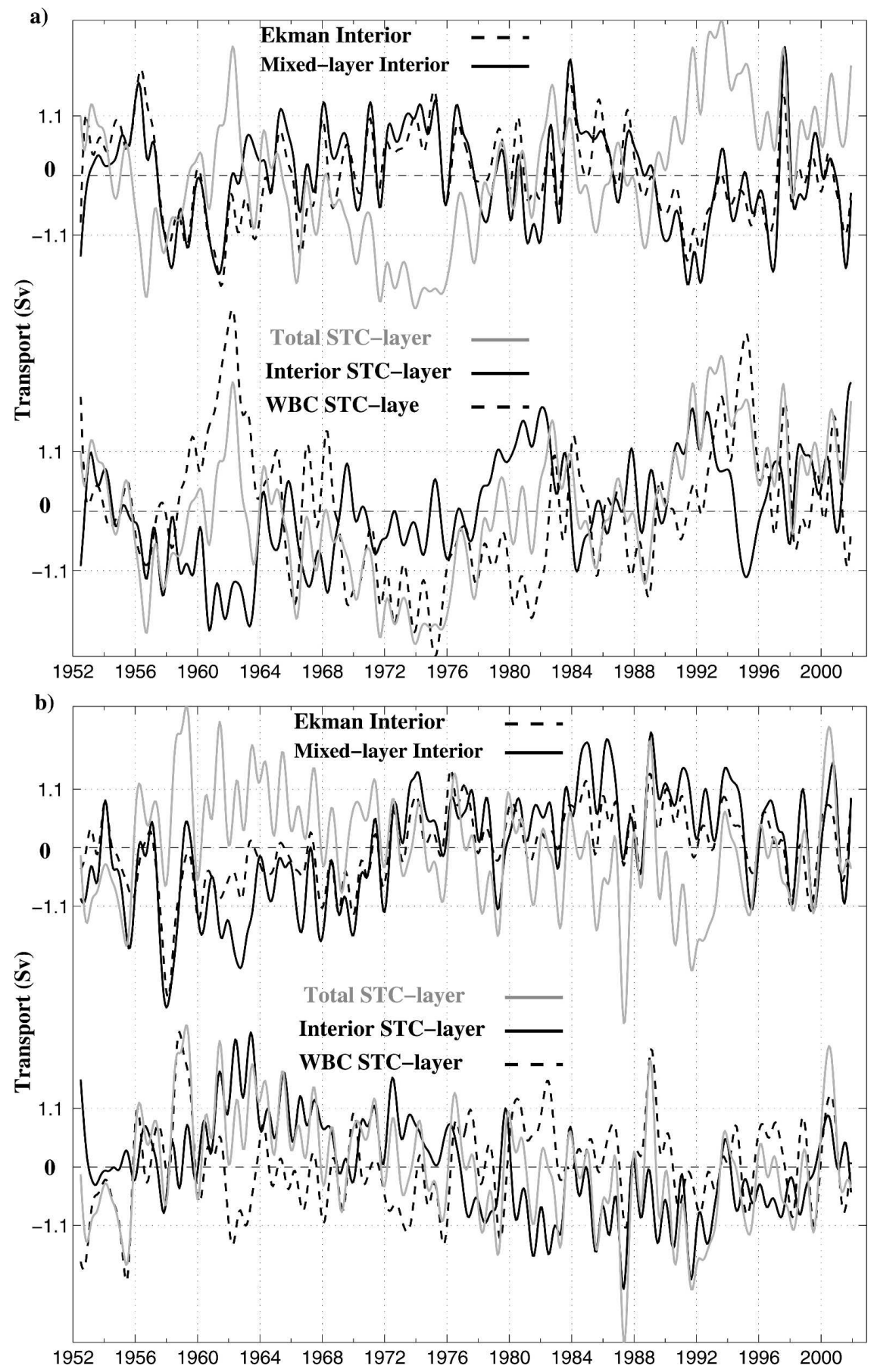

FIG. 6. The 12-month low-pass-filtered anomalies (Sv) from the mean annual cycle of meridional mixed layer transports (solid black) and Ekman transports (dashed, top) and STC layer transports (interior, solid black; WBC, dashed; bottom and total, gray; top and bottom). The transports across (a) $10^{\circ} \mathrm{S}$ and (b) $10^{\circ} \mathrm{N}$ are shown.

for the subtropical North Atlantic at $24^{\circ} \mathrm{N}$ by Lee et al. (1996) and the northern tropical Atlantic by Johns et al. (1998). In GECCO, the interior Sverdrup transports (Figs. 5c,d) and the interior STC layer transports (Figs. 6a,b, bottom) are significantly correlated. In particular, at $10^{\circ} \mathrm{S}$ the correlation is 0.7 for time scales over $5 \mathrm{yr}$, but a phase lead of the WBC part of the STC layer does not fit the Sverdrup mechanism. Alternate mechanisms 
involving a remote forcing mechanism by the wind stress curl farther away from the equator have been suggested in model studies by Lee and Fukumori (2003) and Capotondi et al. (2005) for the Pacific and Hüttl and Böning (2006) for the Atlantic. However, we could not clearly detect such a mechanism in GECCO when comparing variability of the wind stress curl field in the tropical and subtropical Atlantic and transports at $10^{\circ} \mathrm{S}$ and $10^{\circ} \mathrm{N}$. In the following two sections we will disregard the compensating mechanism within the STC layer and will consider only the sum of $\mathrm{WBC}$ and interior.

\section{b. Ekman divergence and STC layer convergence}

Anomalies of the Ekman transports clearly oppose the total STC layer transports at $10^{\circ} \mathrm{S}$ and $10^{\circ} \mathrm{N}$ on longer than interannual time scales (Figs. 6a,b, top), suggesting a baroclinic response, such that wind-forced Ekman transports near the surface are balanced by equatorward flow at STC layer densities. In this case, poleward Ekman transports and subsequent equatorial upwelling pull the equatorward STC-layer transports (see also Schott et al. 2004). We quantify this STC overturning by the Ekman divergence and STC layer convergence at $10^{\circ} \mathrm{S}$ and $10^{\circ} \mathrm{N}$, regardless of the detailed pathways equatorward from these sections. We note that the mean geostrophic flow in the ML is equatorward, and its variability does not correlate significantly with the STC layer convergence.

In the mean, the total equatorward convergence by the STC layer transport across the sections at $10^{\circ} \mathrm{S}$ and $10^{\circ} \mathrm{N}$ (WBC and interior) is $22.5 \mathrm{~Sv}$, which more than balances the divergence of $18.0 \mathrm{~Sv}$ caused by Ekman transports calculated from GECCO wind stress at these two sections. The remaining difference may be explained by poleward STC layer transport near the eastern boundary, amounting to $4.4 \mathrm{~Sv}$, leaving a balance of $18.1 \mathrm{~Sv}$ for STC layer convergence across the whole of $10^{\circ} \mathrm{S}$ and $10^{\circ} \mathrm{N}$. For comparison, the NCEP (ERA-40) wind fields give 17.0 Sv (15.5 Sv) Ekman divergence over the same $50 \mathrm{yr}(44 \mathrm{yr})$, slightly lower than GECCO. Some of the converging and diverging transport may recirculate before reaching the equator, while some of the EUC transport may recirculate without reaching $10^{\circ} \mathrm{S}$ or $10^{\circ} \mathrm{N}$, for example, within TCs. Therefore, we look at the covariability of these latitudes and the equator in section 6 .

Anomalies of the interior Ekman transport divergence from the seasonal cycle are generally low in the 1950s and 1960s with a peak around 1991 (Fig. 7) and show strong covariability with the STC layer convergence anomalies. At time scales over $5 \mathrm{yr}$, the correlation of Ekman divergence with STC layer convergence is 0.85 at about 2-yr lag by the STC layer convergence.
The Fourier spectrum (not shown) has high power for decadal and longer periods, indicating that long-term STC layer variability is largely driven by the winddriven ageostrophic transport near the surface.

\section{Shallow tropical-subtropical pathways}

The anomalies of equatorward STC convergence between $10^{\circ} \mathrm{S}$ and $10^{\circ} \mathrm{N}$, the EUC at $23^{\circ} \mathrm{W}$, and poleward Ekman divergence all show interannual to decadal period variability (Fig. 7a). The Ekman divergence shows some multiyear covariability with the EUC at $23^{\circ} \mathrm{W}$ (Fig. 7a), where time scales over 5 yr are associated with a correlation of 0.8 and a lead of about 1 yr against the EUC. Within the STC loop, we may expect a covariability of the convergence and the EUC, as found by Cheng et al. (2007) in a model study of the Pacific. In GECCO the filtered time series show that on time scales over $5 \mathrm{yr}$ the correlation is 0.85 , and the EUC leads by $1 \mathrm{yr}$, in contrast to the shorter-term covariability that has close to zero lag. Therefore, our analysis indicates that, unlike on close to interannual time scales, there is an STC loop response for $5 \mathrm{yr}$ to decadal STC variability, initiated by increased wind stress near the surface at $10^{\circ} \mathrm{S}-\mathrm{N}$, followed by an enhanced EUC transport and later by an increased STC layer convergence at $10^{\circ} \mathrm{S}-\mathrm{N}$.

To quantify the effect of the STC loop on the equatorial Atlantic, we compare the Ekman divergence and the STC layer convergence at $10^{\circ} \mathrm{S}-\mathrm{N}$ to the ocean heat content in the top $400 \mathrm{~m}$ in a $\pm 3^{\circ}$ latitude band east of $23^{\circ} \mathrm{W}$ (Fig. $7 \mathrm{~b}$ ). The convergence and divergence are generally opposing the heat content, signified by a significant anticorrelation $(-0.7)$ on time scales over $5 \mathrm{yr}$, where the convergence lags by $2-3 \mathrm{yr}$ and the divergence leads by $1 / 2 \mathrm{yr}$. The long-term variability in eastern equatorial heat content, therefore, appears to be partially driven by the strength of the volume transports within the STC loop, which in turn are forced by the wind stress inducing Ekman divergence at $10^{\circ} \mathrm{S}-\mathrm{N}$.

\section{MOC}

\section{a. GECCO and observations}

The MOC transport, here defined as the maximum integrated from the bottom in the zonally summed transport profile, amounts to $13.5 \mathrm{~Sv}$ in GECCO at $10^{\circ} \mathrm{S}$, and similar at $10^{\circ} \mathrm{N}$ where the value is $14.2 \mathrm{~Sv}$. This is in agreement with the recent Atlantic-wide inverse model of Lumpkin and Speer (2003) for $10^{\circ} \mathrm{S}$, who obtained $16 \pm 3 \mathrm{~Sv}$, but significantly (with respect to the estimate error) lower than the analysis of Talley et al. (2003), who determined an MOC of about $18 \mathrm{~Sv}$ throughout the tropical and subtropical Atlantic in a 


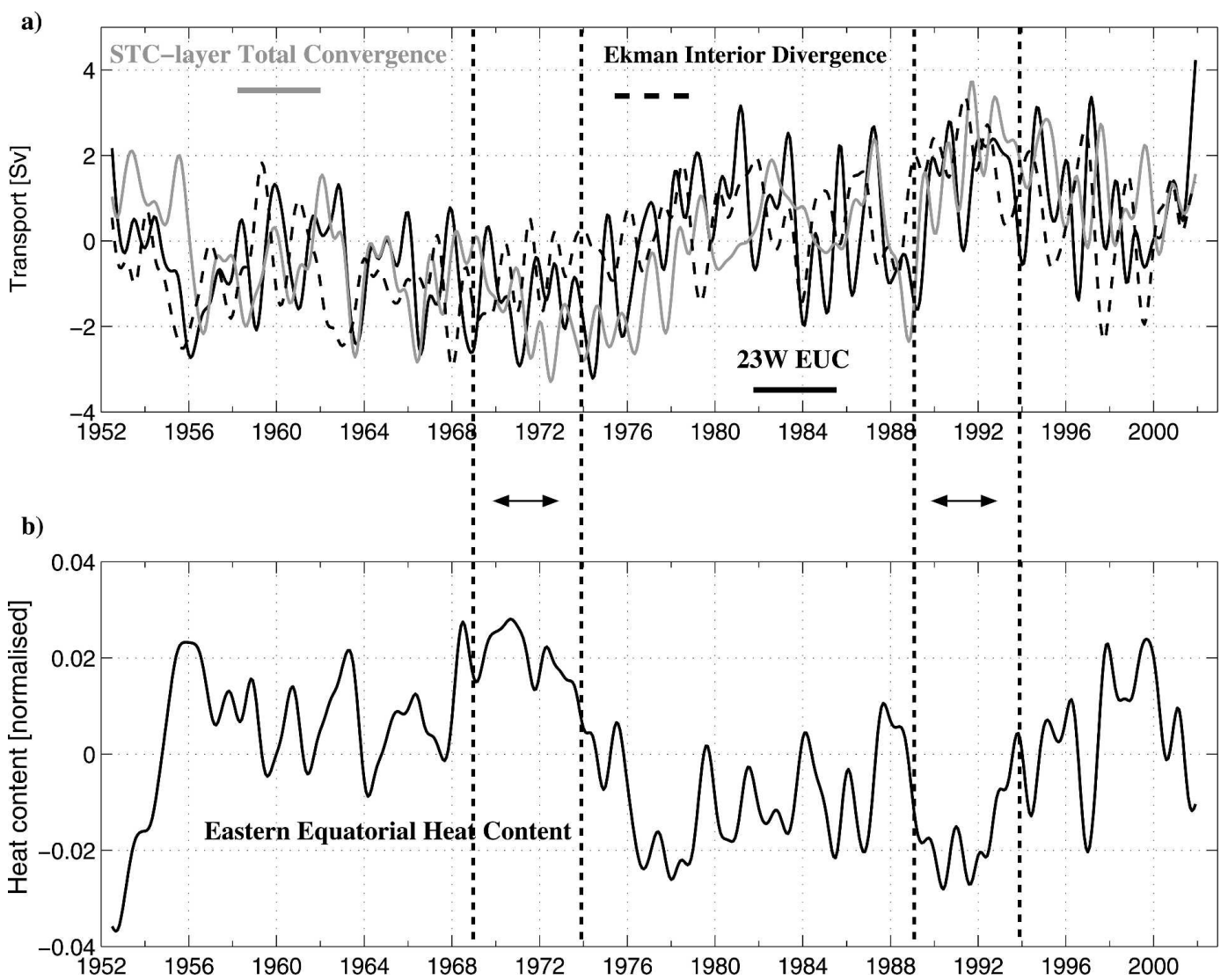

FIG. 7. STC loop-related anomalies (12-month low-pass filtered). (a) Ekman transport divergence $10^{\circ} \mathrm{S}-\mathrm{N}$ (dashed), STC layer transport convergence $10^{\circ} \mathrm{S}-\mathrm{N}$ (gray) and zonal STC layer transports by the EUC at $23^{\circ} \mathrm{W}$ (solid black). (b) The eastern equatorial heat content $3^{\circ} \mathrm{S}-\mathrm{N}, 23^{\circ} \mathrm{W}$ to the eastern boundary (black; units are normalized by the mean). The thick vertical dashed lines mark the time periods analyzed in section $8 \mathrm{~d}$.

global solution based on subjectively referenced geostrophic sections. The global inverse model of $\mathrm{Ga}-$ nachaud (2003) yielded an even higher MOC rate, of $20 \pm 4 \mathrm{~Sv}$. Thus, GECCO is at the low end of the range of MOC estimates in the tropical Atlantic. Note that our measure of the MOC incorporates not only the northern overturning cell, consisting of southward deep-water transport compensating near-surface northward transport, but also the southern cell, which includes the northward-flowing Antarctic Bottom Water (AABW). However, if the southern cell is closed within the lower limb of the MOC changes in AABW transport will not influence MOC variability. We will not go into further detail about the different approaches to estimate MOC but will rather concentrate on the circulatory components of the MOC variability at $10^{\circ} \mathrm{S}$ in the following section.

\section{b. MOC components at $10^{\circ} \mathrm{S}$}

An important question for monitoring the MOC is how its meridional transport components vary in time and how they are related to each other at a particular latitude. Here, we will focus on $10^{\circ} \mathrm{S}$, where we have identified the major transport pathways associated with the STC layer circulation and the near-surface winddriven transport. Section 5 showed that the Sverdrup transports at $10^{\circ} \mathrm{S}$ are well correlated with the interior STC layer transports. However, we use the Sverdrup transports to account for most of the interior geostrophic transport, away from the WBC, as they are more easily determined if found useful for contributing to an MOC index. Figure 8 shows the MOC, NBUC (total transport to $1200 \mathrm{~m}$ ), and the Sverdrup transport anomalies at $10^{\circ} \mathrm{S}$. The most striking feature of the variability is a reduction in all transports during roughly the first decade. Köhl et al. (2007) describe the modeling of the MOC variability during the first $10 \mathrm{yr}$ as problematic, since spinup processes mask the natural variability during this period. They describe a strong response to unresolved processes associated with the overflows. Köhl and Stammer (2007, manuscript submitted to $J$. Phys. Oceanogr.) confirm this characterization in their 
a)

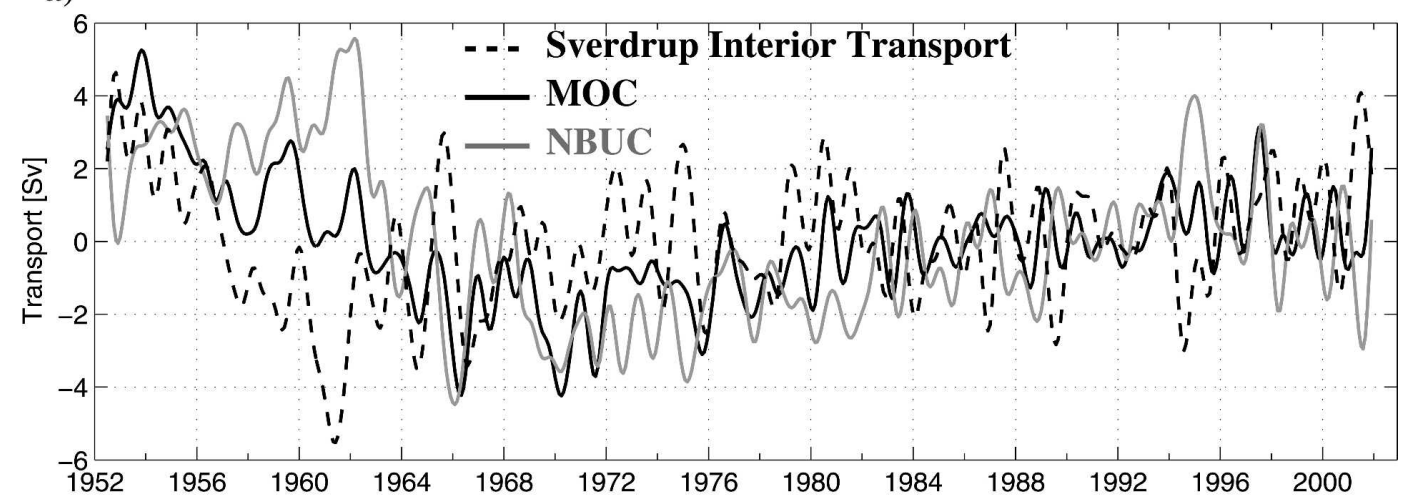

b)

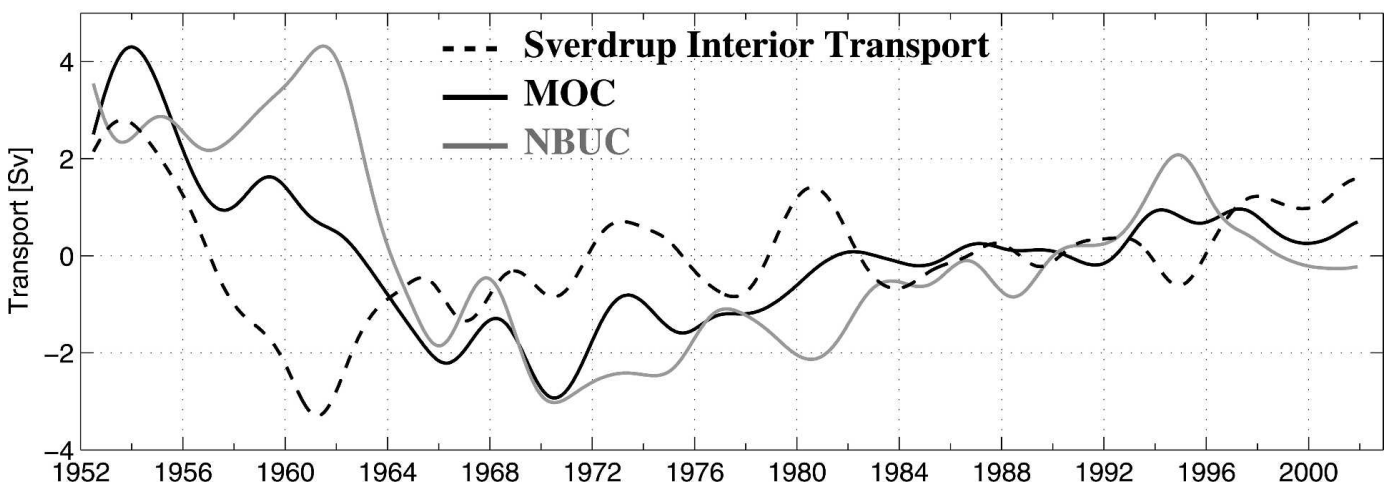

FIG. 8. MOC (solid black), NBUC (gray), and Sverdrup (dashed) transport anomalies at $10^{\circ} \mathrm{S}$. Time series are low-pass filtered: (a) 12 month and (b) 4 yr.

MOC study with the GECCO solution. We therefore limit the analysis of the MOC to the period after 1962.

In general, the NBUC most closely follows the MOC variability on interannual as well as longer time scales, while the Sverdrup transports partially compensate the NBUC signal; for example, the Sverdrup transports increase after 1962 whereas the NBUC and MOC decrease and subsequently increase after 1970 (Fig. 8). While the NBUC alone explains $36 \%$ of the MOC variance on interannual and longer time scales, the sum of the NBUC and the Sverdrup transports explains substantially more (viz., $65 \%$ ). For time scales of several years and more, the MOC variance explained by the combined Sverdrup transport and NBUC is even further increased (to $85 \%$ ). In comparison, the NBUC alone explains $63 \%$ of the MOC variance on such time scales and the Sverdrup transports only $25 \%$.

\section{Discussion and conclusions}

We have analyzed an assimilation run of GECCO for the time period 1952-2001 for the mean circulation and interannual to decadal deviations from the mean seasonal cycle. We focused on the region $10^{\circ} \mathrm{S}-10^{\circ} \mathrm{N}$ and analyzed transports across sections along $10^{\circ} \mathrm{S}$ and $10^{\circ} \mathrm{N}$, which we selected because they separate the tropical belt from the subtropics in the Atlantic, and we looked for potential relations with the equatorial circulation. Given the coarse horizontal resolution, we found relatively good overall agreement of the mean upperlayer transports in the GECCO 50-yr run in comparison with available observations, apart from significant differences in the near-equatorial current structure. The difference in the structure and extent of the WBCs and the zonal equatorial currents are likely due to the coarse horizontal resolution in GECCO and the associated choice of mixing parameterization necessary to provide stability of the model.

\section{a. Forcing adjustment in GECCO}

We compared the wind stresses produced by GECCO with those of the starting values of the forcing, which is the NCEP-National Center for Atmospheric Research (NCAR) reanalysis. As an alternative long-term syn- 
thesis product to NCEP we also included the ERA-40 wind stress product from ECMWF for comparison. Anomalies of transports were derived with respect to the mean annual cycles, and regarding the intraseasonal to interannual wind stress modification of GECCO it was found that neither the variance of Ekman nor Sverdrup transports across $10^{\circ} \mathrm{S}$ and $10^{\circ} \mathrm{N}$ noticeably differ from those based on NCEP. Although the amplitude of variability is similar in all three wind products, there are several times with considerable changes in Ekman and Sverdrup transport anomalies throughout the tropical Atlantic due to the forcing adjustment in GECCO (Fig. 5).

Strength and distribution of the wind stress forcing have been shown to strongly influence the circulation patterns in general circulation models (Lazar et al. 2002; Inui et al. 2002). Through the assimilation process and the adjustments seen in Fig. 5 GECCO has the potential to weaken the dependence of the model circulation on the forcing (in this case NCEP). Stammer et al. (2004) have shown in a comparison of wind stress fields from an 11-yr run of ECCO with those from NCEP and measurements from the NSCAT scatterometer that ECCO improves the NCEP values on a global scale. However, in the North Atlantic they found a worsening of the NCEP fields by the assimilation. This may be explained by a projection of model error onto the wind stress estimated by ECCO. For example, the effects of those equatorial circulation features that are not reproduced by the coarse model resolution have to be somehow accounted for by the wind stress forcing to improve the fit of the assimilation to the data.

\section{b. The STC loop}

STC divergences/convergences show small interannual variations, less than $\pm 2 \mathrm{~Sv}$, which were also found in simulation model studies by Hüttl and Böning (2006) and Kröger et al. (2005). The correlation between poleward-diverging Ekman transports, the EUC at $23^{\circ} \mathrm{W}$ and the STC layer convergence suggests a lagged response of the STC loop to the wind-forced Ekman transport at $10^{\circ} \mathrm{S}-\mathrm{N}$ on decadal time scales. Hüttl and Böning (2006) also showed such covariability in a purely thermohaline-forced model run and a strong decrease in correlation toward the eastern parts of the EUC. This is in contrast to GECCO, where the high correlation of STC divergences/convergences with eastern equatorial heat content suggests that there is a strong influence of the long-term STC loop variability on the upper eastern equatorial Atlantic.

Particle tracking using the GECCO velocity fields (not shown) indicates that the loop is not completely closed, so that near-surface (wind driven) divergence does not entirely return into the STC layer via subduction in the subtropics. However, the particle paths also show that, at least in the south, much of the nearsurface water is subducted into the STC layer within the broad sSEC.

\section{c. MOC variability and Sverdrup response}

Our analysis in section $7 \mathrm{~b}$ shows that the sum of the NBUC and the interior Sverdrup transport explain a significant amount of MOC variability in GECCO at $10^{\circ} \mathrm{S}$. At least part of this can be explained by the Sverdrup transport partially compensating the NBUC on interannual to decadal time scales (Fig. 8). Indeed, there is a strong anticorrelation $(-0.55)$ between the NBUC and the interior Sverdrup transport on interannual to 5-yr time scales, with a few months lag by the NBUC. Following Lee and Marotzke (1998) regarding the decomposition of the MOC into modes related to the Ekman transport, geostrophic shears, and external (barotropic) effects, Sime et al. (2006) found in their study of the Third Hadley Centre Coupled OceanAtmosphere General Circulation Model (HadCM3) simulation model that the external, or barotropic, mode is strongly correlated with the Sverdrup transport at $10^{\circ} \mathrm{S}$. This supports the argument that the return transport in the NBUC caused by the Sverdrup transport has to be considered when trying to explain MOC variability.

\section{d. Multidecadal changes}

We have shown that, in particular on time scales over $5 \mathrm{yr}$, a large part of the MOC variability at $10^{\circ} \mathrm{S}$ can be explained by the NBUC, which is improved by including the Sverdrup transports. To quantify the multidecadal variability, we show the difference between two time averages of the ML and STC layer circulation in the tropical Atlantic, which are associated with distinct levels of the transports under study: 1969-73 and 198993 (Fig. 9; Table 1).

Over the $20 \mathrm{yr}$, the transport increase in STC convergence by $3.4 \mathrm{~Sv}$ (Table 1 ) is almost equally due to the interior and the WBC parts, although the latter is entirely due to the NBUC at $10^{\circ} \mathrm{S}$, while the interior portion is partially compensated by the poleward STC layer transport near the eastern boundary. The transport difference over the $20 \mathrm{yr}$ for Ekman divergence and interior STC layer convergence is similar (2.8 and 3.4 Sv, respectively; Table 1). The EUC STC layer transport increases by $2.6 \mathrm{~Sv}$ between both time periods, in agreement with an Ekman pulled STC loop, whereas the heat content in the upper $400 \mathrm{~m}$ decreases. The equatorial current system is likely to be influenced 
a)

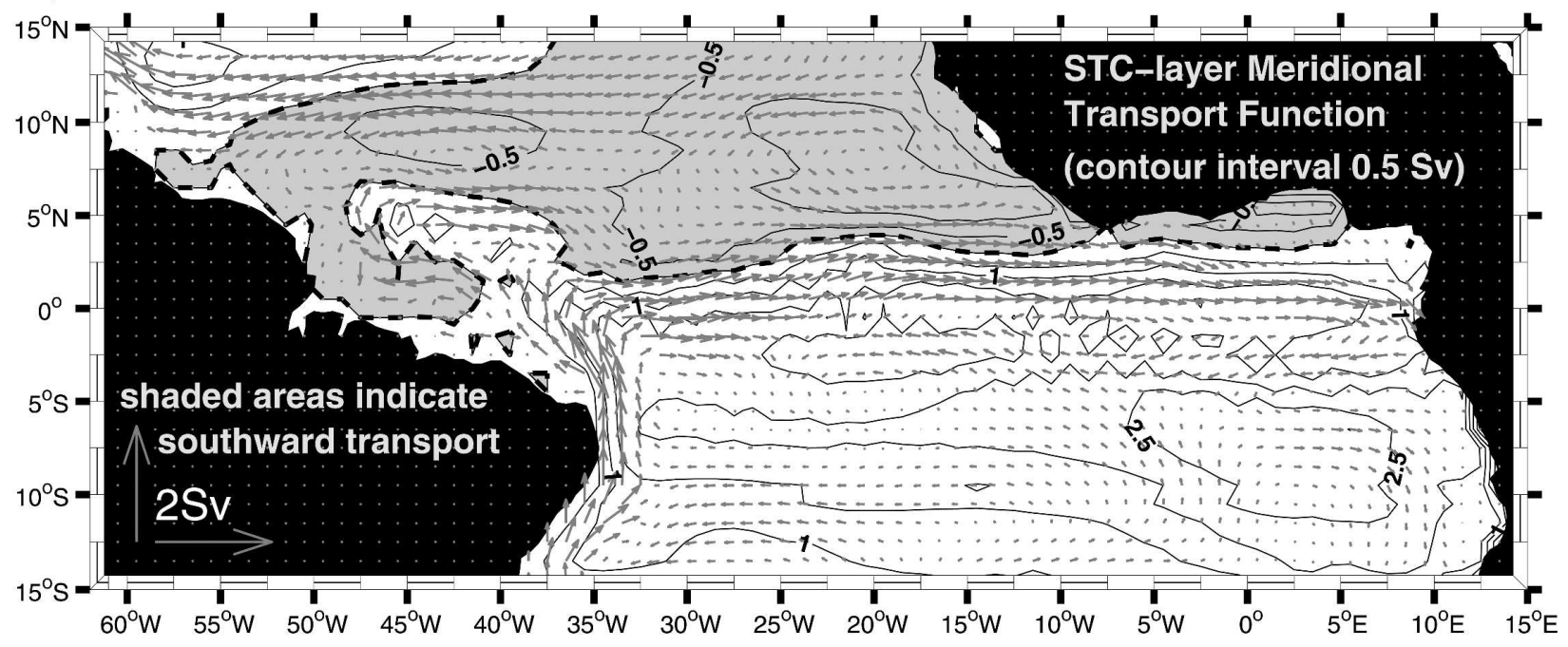

b)

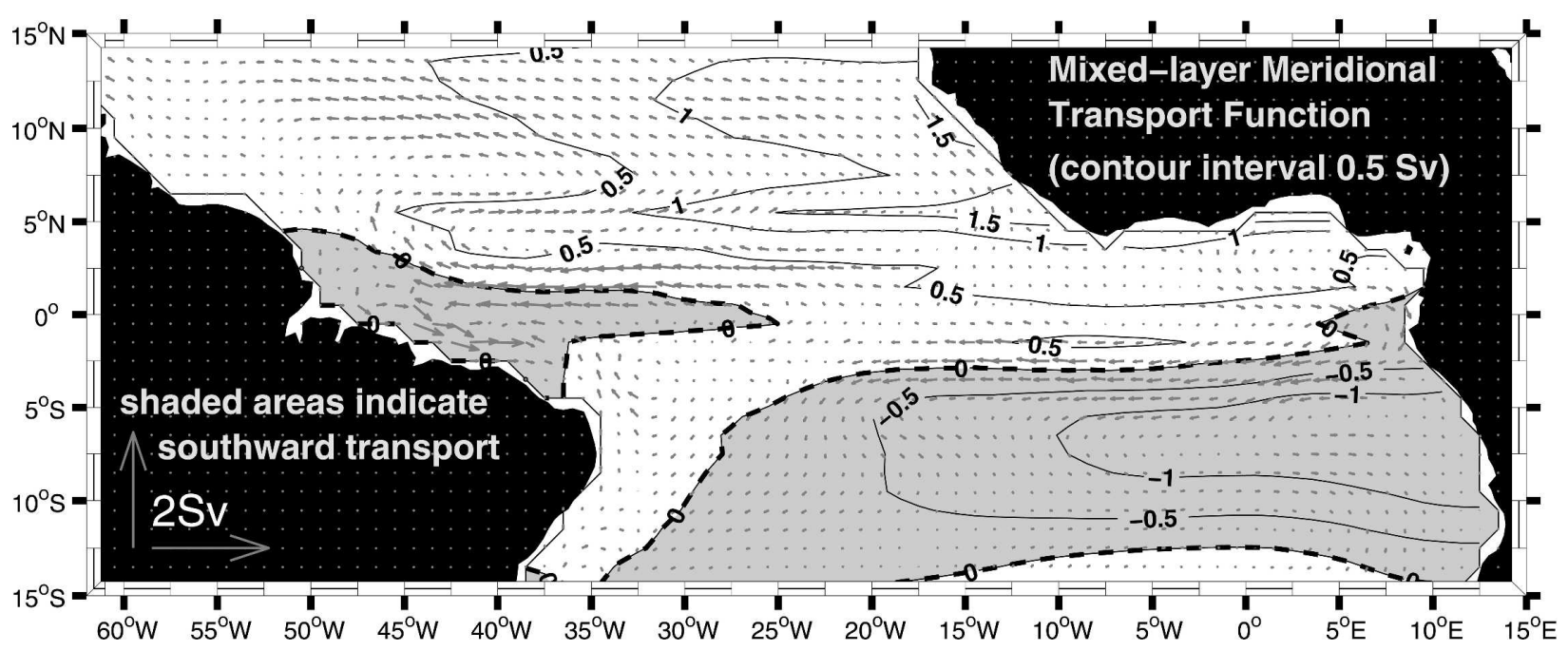

FIG. 9. Differences in layer transports and vector fields between 5-yr means, 1969-73 and 1989-93. The pseudostreamfunction (see text for definition) in the (a) STC layer and (b) the mixed layer.

by circulation other than the STC, such as the tropical cell loop closer to the equator. The MOC increases by 2.2 Sv and the NBUC by $3.1 \mathrm{~Sv}$ in the $20 \mathrm{yr}$, and is in agreement with a strong MOC signal in the WBC found in simulation model studies (Hüttl and Böning 2006). The ML divergence, on the other hand, is fairly well spread across both hemispheres. This is mainly due to the similarity of the strength of the wind forcing and resulting Ekman transport at $10^{\circ} \mathrm{S}$ and $10^{\circ} \mathrm{N}$, although the (equatorward) geostrophic component accounts for about $1 / 3$ of the total ML transport. Only a very small difference over the $20 \mathrm{yr}$ is evident in the Sverdrup transports, indicating that the geostrophic ML trans- port on multidecadal time scales is due to that part of the MOC variability not related to the local wind stress curl. This is in agreement with Hüttl and Böning (2006) who showed in a high-resolution simulation model that multidecadal MOC variability in the tropical Atlantic is related to remote changes in the subpolar North Atlantic.

\section{e. Concluding remarks}

The GECCO synthesis provides an opportunity to analyze physical processes that would otherwise be difficult to describe on the basis of localized observations alone. The dynamically consistent assimilation scheme 
TABLE 1. Changes in 5-yr mean volume transports from the time periods 1969-73 and 1989-93. Values for transports through different sections are shown: the convergence (positive equatorward) and divergence (positive poleward) through $10^{\circ} \mathrm{N}-\mathrm{S}$ and the EUC zonal transports (positive eastward) at $23^{\circ} \mathrm{W}$. Values of eastern equatorial heat content are normalized as in Fig. $7 \mathrm{~b}$.

\begin{tabular}{lrcc}
\hline \hline \multicolumn{4}{c}{$\begin{array}{c}\text { Volume transports and differences } \\
\text { [Sv; with std dev of 5-yr means in “()"] }\end{array}$} \\
\hline & $1969-73$ & $1989-93$ & Difference \\
& $(\mathrm{P} 1)$ & $(\mathrm{P} 2)$ & $(\mathrm{P} 2-\mathrm{P} 1)$ \\
\hline STC layer convergence & $20.8(1.6)$ & $24.2(3.1)$ & 3.4 \\
STC layer interior & $8.9(1.6)$ & $10.7(2.2)$ & 1.8 \\
STC layer WBC & $11.9(1.0)$ & $13.5(1.4)$ & 1.6 \\
Ekman interior divergence & $17.0(2.5)$ & $19.8(3.0)$ & 2.8 \\
ML interior divergence & $8.1(1.7)$ & $10.0(2.1)$ & 1.9 \\
EUC STC layer 23 ${ }^{\circ} \mathrm{W}$ & $11.7(5.0)$ & $14.3(5.4)$ & 2.6 \\
NBUC 10 ${ }^{\circ}$ S (0-1200 m) & $18.5(2.2)$ & $21.6(1.5)$ & 3.1 \\
MOC 10 $\mathrm{S}$ & $11.5(3.2)$ & $13.7(3.2)$ & 2.2 \\
Sverdrup interior 10 ${ }^{\circ} \mathrm{S}$ & $-3.5(2.9)$ & $-3.2(2.9)$ & 0.3 \\
Eastern equatorial heat & $43.4(0.7)$ & $41.9(1.0)$ & -1.5 \\
$\quad$ content (normalized) & & & \\
\hline
\end{tabular}

does, unlike other available products, not introduce artificial source or sink terms into the ocean stratification to accommodate the fit to data. However, the price paid for this dynamically consistent way of estimation is that unresolved processes (model errors) may project onto the estimated forcing. The wind stress may therefore not in all regions be more realistic than the starting fields as has been demonstrated for the 11-yr ECCO fields. Nevertheless, this appears to be an effect on seasonal to interannual time scales, whereas the long-term variability of the wind stress forcing seems to be much less altered.

The smallness of the Atlantic STC convergence stands in interesting contrast to the Pacific where STC convergence changes of $>10 \mathrm{~Sv}$, about one-third of the mean, were found in observations (McPhaden and Zhang 2004). Furthermore, the Atlantic convergence varies by only about $O(10 \%)$ of the mean value. However, a recent analysis of the Pacific STC in GECCO by Schott et al. (2007) did not show trends as large as were seen in McPhaden and Zhang (2004). The same applies to fluctuations in the Ekman divergence. Are the changes in the Pacific really comparatively stronger than in the Atlantic? If so, why? This question poses a puzzle for future studies.

Acknowledgments. The observations of IFM-GEOMAR used here were supported by the German Bundesministerium für Bildung, Wissenschaft und Forschung (BMBF) as part of the German CLIVAR/marin program (Contract 03F0246A). Part of the work was supported by the BMBF as part of the German ARGO program (Contract 03F0367A). This is a contribution of the Consortium for Estimating the Circulation and Climate of the Ocean (ECCO) funded by the National Oceanographic Partnership Program.

\section{REFERENCES}

Brandt, P., F. A. Schott, C. Provost, A. Kartavtseff, V. Hormann, B. Bourles, and J. Fischer, 2006: Circulation in the central equatorial Atlantic: Mean and intraseasonal to seasonal variability. Geophys. Res. Lett., 33, L07609, doi:10.1029/ 2005 GL025498.

Bretherton, C. S., M. Widmann, V. P. Dymnikov, J. M. Wallace, and I. Bladé, 1999: The effective number of spatial degrees of freedom of a time-varying field. J. Climate, 12, 1990-2009.

Capotondi, A., M. A. Alexander, C. Deser, and M. J. McPhaden, 2005: Anatomy and decadal evolution of the Pacific subtropical-tropical cells (STCs). J. Climate, 18, 3739-3758.

Cheng, W., M. J. McPhaden, D. Zhang, and E. J. Metzger, 2007: Recent changes in the Pacific subtropical cells inferred from an eddy-resolving ocean circulation model. J. Phys. Oceanogr., 37, 1340-1356.

Chereskin, T. K., and D. Roemmich, 1991: A comparison of measured and wind-derived Ekman transport at $11^{\circ} \mathrm{N}$ in the Atlantic Ocean. J. Phys. Oceanogr., 21, 869-878.

Foltz, G. R., S. A. Grodsky, J. A. Carton, and M. J. McPhaden, 2003: Seasonal mixed layer heat budget of the tropical Atlantic Ocean. J. Geophys. Res., 108, 3146, doi:10.1029/ 2002JC001584.

Fratantoni, D. M., W. E. Johns, T. L. Townsend, and H. E. Hurlburt, 2000: Low-latitude circulation and mass transport pathways in a model of the tropical Atlantic Ocean. J. Phys. Oceanogr., 30, 1944-1966.

Ganachaud, A., 2003: Large-scale mass transports, water mass formation, and diffusivities estimated from World Ocean Circulation Experiment (WOCE) hydrographic data. J. Geophys. Res., 108, 3213, doi:10.1029/2002JC001565.

Giarolla, E., P. Nobre, M. Malagutti, and L. P. Pezzi, 2005: The Atlantic Equatorial Undercurrent: PIRATA observations and simulations with GFDL Modular Ocean Model at CPTEC. Geophys. Res. Lett., 32, L10617, doi:10.1029/ 2004GL022206.

Gill, A. E., 1982: Atmosphere-Ocean Dynamics. Academic Press, $662 \mathrm{pp}$.

Grodsky, S. A., and J. A. Carton, 2002: Surface drifter pathways originating in the equatorial Atlantic cold tongue. Geophys. Res. Lett., 29, 62-65.

Hazeleger, W., and S. Drijfhout, 2006: Subtropical cells and meridional overturning circulation pathways in the tropical Atlantic. J. Geophys. Res., 111, C03013, doi:10.1029/ 2005JC002942.

Hüttl, S., and C. W. Böning, 2006: Mechanisms of decadal variability in the shallow subtropical-tropical circulation of the Atlantic Ocean: A model study. J. Geophys. Res., 111, C07011, doi:10.1029/2005JC003414.

Inui, T., A. Lazar, P. Malanotte-Rizzoli, and A. Busalacchi, 2002: Wind stress effects on subsurface pathways from the subtropical to tropical Atlantic. J. Phys. Oceanogr., 32, 22572276.

Jochum, M., and P. Malanotte-Rizzoli, 2001: Influence of the meridional overturning circulation on tropical-subtropical pathways. J. Phys. Oceanogr., 31, 1313-1323. 
Johns, W. E., T. N. Lee, R. C. Beardsley, J. Candela, R. Limeburger, and B. Castro, 1998: Annual cycle and variability of the North Brazil Current. J. Phys. Oceanogr., 28, 103-128.

Köhl, A., D. Dommenget, K. Ueyoshi, and D. Stammer, 2006: The Global ECCO 1952 to 2001 ocean synthesis. The ECCO Report Series, Tech. Rep. 40, 44 pp. [Available online at http:// www.ecco-group.org/pdfs/reports/report_40.pdf.]

- D. Stammer, and B. Cornuelle, 2007: Interannual to decadal changes in the ECCO global synthesis. J. Phys. Oceanogr., 37, 313-337.

Kröger, J., A. J. Busalacchi, J. Ballabrera-Poy, and P. MalanotteRizzoli, 2005: Decadal variability of shallow cells and equatorial sea surface temperature in a numerical model of the Atlantic. J. Geophys. Res., 110, C12003, doi:10.1029/ 2004JC002703.

Lazar, A., T. Inui, P. Malanotte-Rizzoli, A. J. Busalacchi, L. Wang, and R. Murtugudde, 2002: Seasonality of the ventilation of the tropical Atlantic thermocline in an ocean general circulation model. J. Geophys. Res., 107, 3104, doi:10.1029/ $2000 \mathrm{JC} 000667$

Lee, T., and J. Marotzke, 1998: Seasonal cycles of meridional overturning and heat transport of the Indian Ocean. J. Phys. Oceanogr., 28, 962-983.

— tropical-subtropical exchange in the Pacific Ocean: Boundary versus interior pycnocline transports. J. Climate, 16, 40224041.

Lee, T. N., W. E. Johns, R. J. Zantopp, and E. R. Fillenbaum, 1996: Moored observations of western boundary current variability and thermohaline circulation at $26.5^{\circ} \mathrm{N}$ in the subtropical North Atlantic. J. Phys. Oceanogr., 26, 962-983.

Liu, Z., S. G. H. Philander, and R. C. Pacanowski, 1994: A GCM study of tropical-subtropical upper-ocean water exchange. $J$. Phys. Oceanogr., 24, 2606-2623.

Lumpkin, R., and K. Speer, 2003: Large-scale vertical and horizontal circulation in the North Atlantic Ocean. Deep-Sea Res. I, 33, 1902-1920.

- , and S. L. Garzoli, 2005: Near-surface circulation in the tropical Atlantic Ocean. Deep-Sea Res. I, 52, 495-518.

Malanotte-Rizzoli, P., P. K. Hedstrom, H. Arango, and D. B. Haidvogel, 2000: Water mass path-ways between the subtropical and tropical ocean in a climatological simulation of the North Atlantic ocean circulation. Dyn. Atmos. Oceans, 32, 331-371.

Marshall, J., A. Adcroft, C. Hill, L. Perelman, and C. Heisey, 1997: A finite-volume, incompressible Navier Stokes model for studies of the ocean on parallel computers. J. Geophys. Res., 102, 5753-5766.

McCreary, J. P., and P. Lu, 1994: Interaction between the subtropical and equatorial ocean circulations: The subtropical cell. J. Phys. Oceanogr., 24, 466-497.

McPhaden, M. J., and D. X. Zhang, 2002: Slowdown of the me- ridional overturning circulation in the upper Pacific Ocean. Nature, 415, 603-608.

- and D. Zhang, 2004: Pacific Ocean circulation rebounds. Geophys. Res. Lett., 31, L18301, doi:10.1029/2004GL020727.

Molinari, R. L., S. Bauer, D. Snowden, G. C. Johnson, B. Bourles, Y. Gouriou, and H. Mercier, 2003: A comparison of kinematic evidence for tropical cells in the Atlantic and Pacific Oceans. Interhemispheric Water Exchange in the Atlantic Ocean, G. J. Goni, and P. Malanotte-Rizzoli, Eds., Elsevier Oceanographic Series, Vol. 68, Elsevier, 269-286.

Schott, F. A., J. P. McCreary, and G. C. Johnson, 2004: Earth climate: The ocean-atmosphere interaction. Shallow Overturning Circulations of the Tropical-Subtropical Oceans, Geophys. Monogr., Vol. 147, Amer. Geophys. Union, 231-304.

- M. Dengler, R. Zantopp, L. Stramma, J. Fischer, and P. Brandt, 2005: The shallow and deep western boundary circulation of the South Atlantic at $5^{\circ}-11^{\circ}$ S. J. Phys. Oceanogr., 35, 2031-2053.

_ W. Wang, and D. Stammer, 2007: Variability of the Pacific subtropical cells in the 50-year ECCO assimilation. Geophys. Res. Lett., 34, L05604, doi:10.1029/2006GL028478.

Schouten, M. W., R. P. Matano, and T. P. Strub, 2005: A description of the seasonal cycle of the equatorial Atlantic from altimeter data. Deep-Sea Res. I, 52, 477-493.

Sime, L. C., D. P. Stevens, K. J. Heywood, and K. I. C. Oliver, 2006: A decomposition of the Atlantic meridional overturning. J. Phys. Oceanogr., 36, 2253-2270.

Snowden, D. P., and R. L. Molinari, 2003: Subtropical cells in the Atlantic Ocean: An observational summary. Interhemispheric Water Exchange in the Atlantic Ocean, G. J. Goni, and P. Malanotte-Rizzoli, Eds., Elsevier Oceanographic Series, Vol. 68, Elsevier, 287-312.

Stammer, D., K. Ueyoshi, A. Köhl, W. G. Large, S. A. Josey, and C. Wunsch, 2004: Estimating air-sea fluxes of heat, freshwater, and momentum through global ocean data assimilation. J. Geophys. Res., 109, C05023, doi:10.1029/2003JC002082.

Stramma, L., and M. England, 1999: On the water masses and mean circulation of the South Atlantic Ocean. J. Geophys. Res., 104, 20 863-20 883.

-, and F. Schott, 1999: The mean flow field of the tropical Atlantic Ocean. Deep-Sea Res. II, 46, 279-303.

Talley, L. D., J. L. Reid, and P. E. Robbins, 2003: Data-based meridional overturning streamfunctions for the global oceans. J. Climate, 16, 3213-3226.

Wilson, W. D., E. Johns, and R. L. Molinari, 1994: Upper layer circulation in the western tropical North Atlantic Ocean during August 1989. J. Geophys. Res., 99, 22 513-22 523.

Wunsch, C., 1996: The Ocean Circulation Inverse Problem. Cambridge University Press, $437 \mathrm{pp}$.

Zhang, D., M. J. McPhaden, and W. E. Johns, 2003: Observational evidence for flow between the subtropical and tropical Atlantic: The Atlantic tropical cells. J. Phys. Oceanogr., 33, 1783-1797. 